\title{
Neonatal encephalopathy with a pungent body odour
}

\author{
V Walker, G A Mills, P-M Fortune, R Wheeler
}

\begin{abstract}
A neonate had transient unexplained bleeding into the gut, severe encephalopathy, and an abnormal pungent body odour. An inherited metabolic defect was excluded. The malodour was due to methanethiol and hydrogen sulphide, identified in urine. These sulphur compounds may have contributed to encephalopathy. Colonic bacteria were the probable source. (Arch Dis Child 1997;77:F65-F66)
\end{abstract}

Keywords: encephalopathy; methanethiol; body odour; gut bacteria

A baby presenting with a neurological disturbance and an abnormal body odour must be investigated urgently for a possible inherited metabolic disorder. Tests were all negative in the case reported. Eventually methanethiol and hydrogen sulphide were identified as the cause of the malodour. They were probably produced in grossly increased amounts in the colon by bacterial fermentation due to very unusual circumstances.

\section{Case report}

The second child of non-consanguineous Caucasian parents was delivered vaginally at 37 weeks gestation after a normal pregnancy; his birthweight was $2.82 \mathrm{~kg}$. The Apgar score was 9 at 1,3 , and 5 minutes and there was no perinatal distress. He had major problems for 16 days.

Table 1 Results of biochemical investigations with encephalopathy (days 10 to 14)

Department of
Chemical Pathology,
Southampton General
Hospital,
Tremona Road,
Southampton
S016 6YD
V Walker
Department of Child
Health
P-M Fortune
R Wheeler
Division of Chemistry,
University of
Portsmouth
G A Mills
Correspondence to:
Dr V Walker.

\begin{tabular}{|c|c|c|}
\hline & Value & $\begin{array}{l}\text { Reference } \\
\text { range }\end{array}$ \\
\hline \multicolumn{3}{|l|}{ Plasma: } \\
\hline Glucose $(\mathrm{mmol} / \mathrm{l})$ & $6.0-7.0$ & $>2.5$ \\
\hline Bicarbonate $(\mathrm{mmol} / \mathrm{l})$ & $22-25$ & $20-24$ \\
\hline Calcium $(\mathrm{mmol} / \mathrm{l})$ & $2.36-2.66$ & $2.20-2.65$ \\
\hline Magnesium (mmol/l) & 1.00 & $0.70-1.00$ \\
\hline AST (IU/1) & 23. & $5-42$ \\
\hline ALT (IU/1) & 8 & $5-42$ \\
\hline Uric acid $(\mathrm{mmol} / \mathrm{l})$ & 0.22 & $0.14-0.34$ \\
\hline $\begin{array}{l}\text { Ammonia }(\mu \mathrm{mol} / \mathrm{l}) \text { (day } \\
14)\end{array}$ & 136 & $\begin{array}{l}<40,<150 \\
\text { sick } \\
\text { newborn }\end{array}$ \\
\hline Amino acids & Normal profile & \\
\hline Methionine $(\mu \mathrm{mol} / \mathrm{l})$ & 35 & $<96$ \\
\hline Tyrosine $(\mu \mathrm{mol} / \mathrm{l})$ & 50 & $<196$ \\
\hline \multicolumn{3}{|l|}{ CSF: } \\
\hline Lactate $(\mathrm{mmol} / \mathrm{l})$ & 1.86 & $<2.00$ \\
\hline \multicolumn{3}{|l|}{ Urine: } \\
\hline Amino acids & $\begin{array}{l}\text { Pungent smell, } \\
\text { normal profile }\end{array}$ & \\
\hline $\begin{array}{l}\text { Methionine } \\
\text { ( } \mu \mathrm{mol} / \mathrm{mmol} \text { creatinine) } \\
\text { Organic acids }\end{array}$ & 25 & $7-27$ \\
\hline Day 11 & $\begin{array}{l}\text { No odour, } \\
\text { normal profile }\end{array}$ & \\
\hline Day 14 & $\begin{array}{l}\text { Pungent smell, } \\
\text { normal profile }\end{array}$ & \\
\hline
\end{tabular}

From days 1 to 12, he passed blood-streaked mucoid stools and seemed to have episodic abdominal pain. On day 10 he had a larger rectal bleed, vomited bile and blood, and had bile stained gastric aspirates for the next 48 hours. He was transfused once only (lowest haemoglobin concentration $120 \mathrm{~g} / \mathrm{l}$ ) and given one bolus of human albumin solution. Necrotising enterocolitis, anatomical bowel obstruction, perforation, midgut malrotation and an enteric gastric duplication cyst were excluded. The coagulation screen and C-reactive protein were normal. Blood and urine cultures showed no growth and faeces were negative for Salmonella, Shigella, and Campylobacter species and enterohaemorrhagic Escherichia coli and Cryptosporidium sp.

He had a neurological disturbance starting with "jitteriness" on day 8 . By day 10 he was irritable on handling, hypertonic, and having severe episodic opisthotonos when his head almost touched his heels. There were bouts of tachypnoea with deep breathing and unassociated episodes of pallor. Opisthotonos and irritability continued to days 13 and 17 , respectively. No cardiac or pulmonary abnormalities were found. An electroencephalogram and head ultrasound scan were normal.

On day 12 there was an abnormal smell around his incubator which pervaded the nursery, and for the next three days his urine had a sharp, pungent, cabbage-like smell. This then disappeared.

Until day 13 he was maintained on nil by mouth, fed parenterally, and given intravenous antibiotics (metronidazole, flucloxacillin, and piperacillin, later changed to ampicillin). By day 18 he was feeding and handling normally. At 11 months of age he was developing and growing normally. He has recurrent wheeze as does his 3 year old brother.

\section{Biochemical investigations}

The combination of encephalopathy with abnormal body odour made an inborn error a near certainty. This was excluded by metabolic tests (table 1) and his rapid recovery. Normal plasma and urine methionine, tyrosine, and organic acids excluded tyrosinaemia type I and other inherited disorders with hypermethioninaemia and a cabbage-like smell. Attempts to identify the malodorous compounds in urine by headspace gas chromatography-mass spectrometry (GC-MS) using standard hospital equipment failed. However, using GC with a dedicated sulphur chemiluminescence detector (Sievers 350B detector), large amounts of methanethiol (methylmercaptan, $\mathrm{CH}_{3} \mathrm{SH}$ ) and hydrogen sulphide $\left(\mathrm{H}_{2} \mathrm{~S}\right)$ were found (fig 1$)$. 


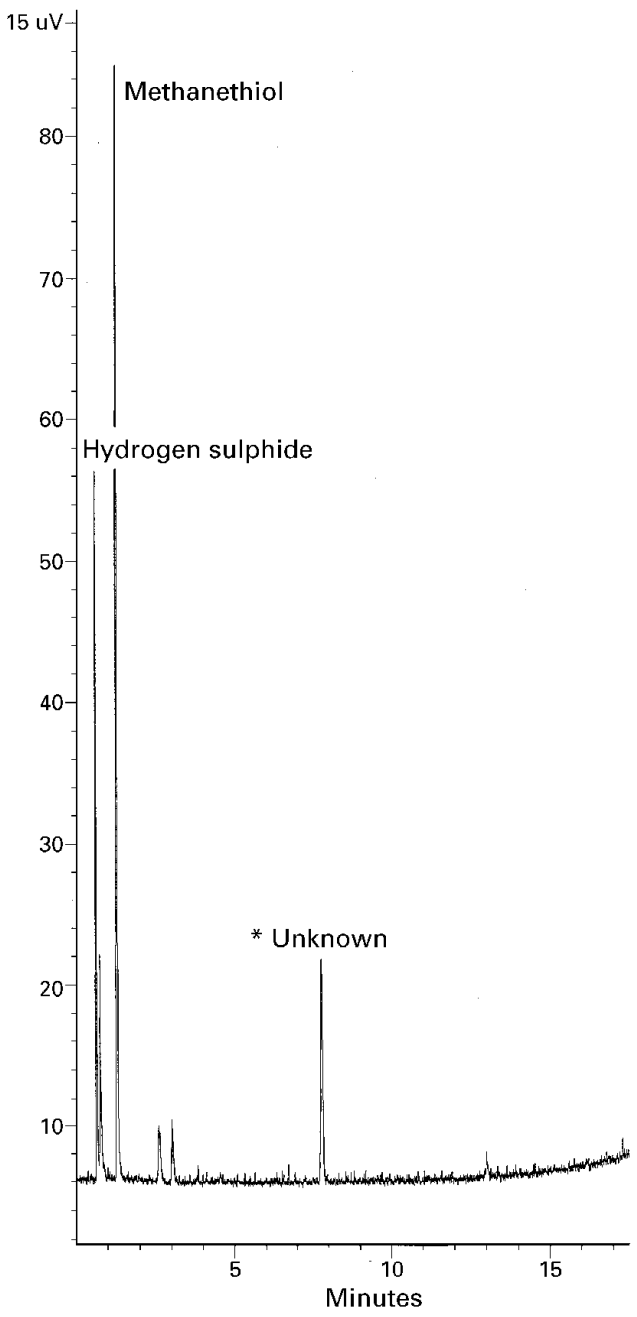

Figure 1 Gas chromatogram of $1000 \mu$ of headspace gas injected with a 10:1 split ratio onto an HP1 cross linked methyl silicon gum column, $30 \times 0.25 \mathrm{~mm}$, film thickness 4 um (Hewlett Packard). Injector temperature $150^{\circ} \mathrm{C}$; oven temperature programme $35^{\circ} \mathrm{C}$ ( 5 minutes) then $5^{\circ} \mathrm{C} / \mathrm{min}$ to $200^{\circ} \mathrm{C}$. Sulphur chemiluminescence detector (Sievers 350B). * Unidentified sulphur compound.

\section{Discussion}

There are three sources of methanethiol in the body. It is produced by the liver during degradation of methionine by the transamination pathway. Production is increased after methionine loading, in patients with hypermethioninaemia due to an inherited defect and in liver disease (controversial). ${ }^{12}$ Secondly, it is produced from sulphur amino acids by fermentative bacteria in the colon, often with $\mathrm{H}_{2} \mathrm{~S}$ and possibly ammonia. ${ }^{3}$ Thirdly, it is formed within intestinal cells by methylation of $\mathrm{H}_{2} \mathrm{~S}$ absorbed from the colon.

Increased liver production is unlikely here and would not have accounted for the $\mathrm{H}_{2} \mathrm{~S}$ found. The compounds were probably produced in the colon. Bleeding into the bowel would have supplied sulphur amino acids, and use of broad spectrum antibiotics may have led to unusual colonisation by a fermentative organism. The compounds were probably present in the urine because of faecal contamination, but no bacteria were cultured from the malodorous urine collected on day 14. The alternative is that they were absorbed from the colon (demonstrated in rats $^{5}$ ) and then excreted. The problem with this explanation is that absorbed methanethiol is converted rapidly to disulphides and sulphate by the liver and perhaps blood cells. ${ }^{5}$ If absorbed compounds were the source they would have to have escaped hepatic detoxification. The only reported patient with methanethiol in urine had massive hepatic necrosis. ${ }^{5}$ In the case reported here liver function tests were normal. On the other hand, closure of the ductus venosus could have been delayed, with diversion of portal blood from the liver to the systemic circulation.

The baby's encephalopathy was almost certainly caused by a transient metabolic abnormality. There was no serious hypoxicischaemic episode, infection, or inherited biochemical defect to explain it. Hyperammonaemia (from the gut?) cannot be excluded as plasma ammonium measurement was delayed until day 14 and was then near our upper acceptable limit. Both $\mathrm{H}_{2} \mathrm{~S}$ and methanethiol are neurotoxic. In rats they cause coma and methanethiol may precipitate respiratory failure. ${ }^{5}$ Brain toxicity of methanethiol is enhanced by ammonia and small amounts of octanoic acid, indicating synergy between these compounds. ${ }^{6}$ By the time the odour was noticed, the encephalopathy was well advanced, suggesting that the thiol compounds were not primary causative agents. They may have contributed, perhaps in synergy with ammonia, if high blood concentrations were achieved. Few clinical laboratories have instruments to detect volatile sulphur compounds. A screening test for $\mathrm{H}_{2} \mathrm{~S}$ in gas from malodorous fluid (lead acetate strip, BDH-Merck, Poole,UK) would help to exclude an inborn error.

We thank Dr RJ Hallett for permission to report his patient.

1 Al Mardini H, Leonard J, Bartlett K, Lloyd S, Record CO. Effect of methionine loading and endogenous hyperme-
thioninaemia on blood mercaptans in man. Clin Chim Acta thioninaemia on bloc

2 Blom HJ, Boers GHJ, van den Elzen JPAM, Gahl WA, Tangerman A. Transamination of methionine in humans. Clin Sci 1989;76:43-9.

3 Kadota H, Ishida Y. Production of volatile sulfur compounds by microorganisms. Ann Rev Microbiol 1972;26:127-38.

4 Weisiger RA, Pinkus LM, Jakoby WB. Thiol $S$-methyltransferase: suggested role in detoxication of intestinal hydrogen sulfide. Biochem Pharmacol 1980;29:2885-7.

5 Blom HJ, Chamuleau RAFM, Rothuizen J, Deutz NEP, Tangerman A. Methanethiol metabolism and its role in the pathogenesis of hepatic encephalopathy in rats and dogs. Hepatology 1990;11:682-9.

6 Zieve L, Doizaki WM, Lyftogt C. Brain methanethiol and ammonia concentrations in experimental hepatic coma and coma induced by injections of various combinations of these substances. F Lab Clin Med 1984;104: 655-64. 